\title{
Celebrating libraries (and humor) every day
}

\author{
By Susan Vazakas
}

\section{A little bumor makes librarians more approachable}

ibrary patrons, particularly those with allconsuming academic workloads, appreciate a little humor in the library. A university science and engineering library is the den of the very serious. They enter, grim-faced, bearing immense organic chemistry tomes (sold by weight at the bookstore), and cardboard boxes filled with circuit boards or plastic models of DNA. They travel from dorm room to class to lab and back again in an unending cycle; their clones become contaminated; their computer programs crash; their proteins denature as soon as they turn their backs.

The people who come to use our Science/ Engineering Library have the weight of the world on their shoulders, and perhaps it is the constant high-intensity level of their existence that makes them so deeply appreciate a wellchosen cartoon or unusual sight when they come to study.

\section{Library decor makes patrons smile}

Our bulletin board always has a selection of cartoons that poke fun at science and technology: air fares that change with continental drift; the poor soul who has taken to applying Heisenberg's uncertainty principle to everything; a crowd of scientists dropping everything and running out the door toward an approaching ice cream truck.

My office door sports a small but choice collection of library cartoons, including the classic complaint by a couple that they have nothing in common because one searches by author and the other by title. Another shows a pristine room filled with neat rows of computer terminals; a forlorn-looking fellow stands in the middle, spraying from a large can labelled "Eau de Library-Essence of Card Catalog Drawer."

In my office is a giant framed poster of the "periodic table of desserts," complete with Latin names and the average number of calories per dessert. This is flanked by a painting of an alchemist in an atmospheric candle-lit room, and an ALA poster featuring the crew of the U.S.S. Enterprise. My window sill is populated by a herd of plastic dinosaurs of various colors and sizes, all creeping, flying, and lumbering toward an unknown destination.

\section{Dinosaur feet}

During final exam week, I wear a pair of woolly dinosaur feet colored a mottled green with large yellow claws. These are a favorite of my coworkers, and patrons bestow delighted smiles as I walk past, even when they are in the throes of designing airfoils or studying enzyme kinetics.

Library patrons have made special trips to my office or the circulation desk to ask how they can get their own copies of the posters. They laugh out loud at the cartoons on the bulletin board, and people passing outside my office stop and say "Ooh, look at the dinosaurs!" (I also use dinosaur models as prizes during my bibliographic instruction session on Chemical Abstracts; they work wonders to loosen up the crowd.)

An occasional charge in the library literature has been that we take ourselves too seriously. It is very admirable that we take our jobs seriously; however, when we take ourselves lightly, the patrons enjoy it, and we become more approachable. And this makes us better able to do our jobs. 


\section{If You Think an Automated Media Tracking System Is a Luxury... \\ Just Try Losing One of These...}

PRECISION ONE ${ }^{\oplus}$ Media Minder" from Brodart Automation in partnership with CRS, Inc. (formerly Canopy Road Software) provides you with an easy to use, PC-based media management program that allows you to take control of your media collection.

The Precision One Media Minder System provides total automation and control of your media center. From check-in to check-out, this is the media tracking system that received one of the highest overall scores in the November 1991 issue of T.H.E. Joumal.

Just imagine ... a feature-laden system that gives you the power to manage your media center's resources in a fully automated environment and at a price you can afford.

\section{For Media Centers}

The Precision One Media Minder Reservation System gives you and your users complete control of your valuable media collection. And it gives your users automated access to all your media resources.

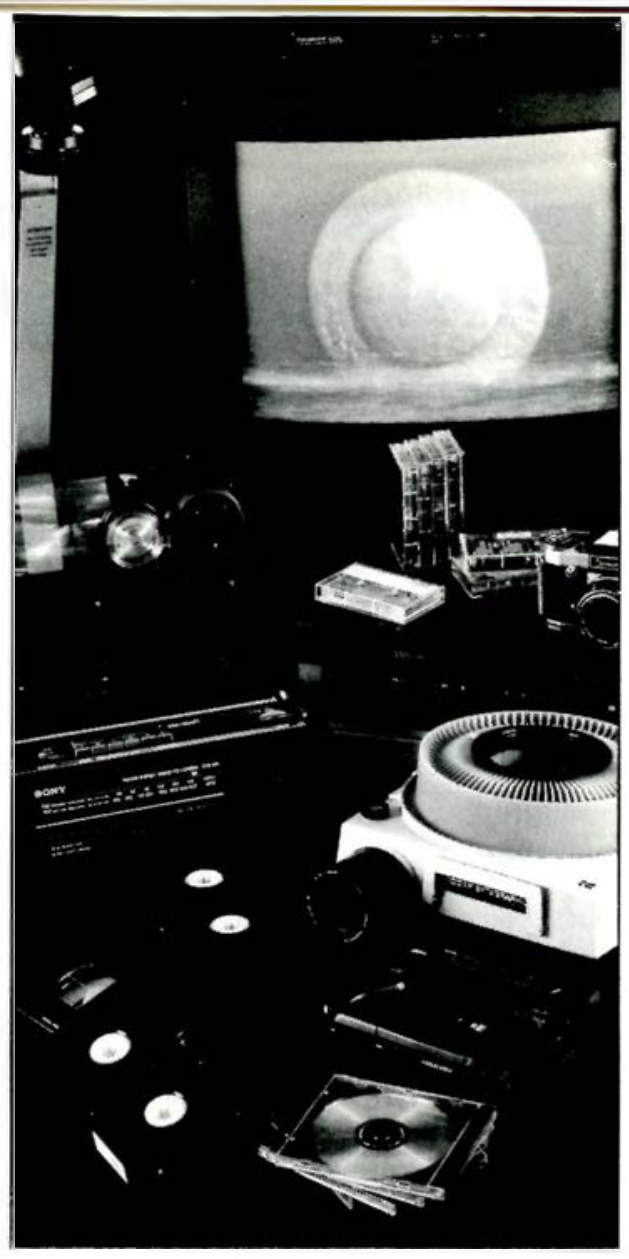

The optional voice board allows educators to make telephone reservations for any piece of $\mathrm{AV}$ material in the collection. For the media center manager, the system tracks the reservation, prints shipping documents and provides for fund accounting if required.

\section{All This and More ...}

- Telephone reservations

- Generation of shipping documents

- Custom profiles

- Full fund accounting

- User control of set-up and installation

- Full MARC record support

So if you want to take full control of your library's valuable media collection find out more about Precision One Media Minder. Call us today at:

800-233-8467, ext. 522

In Canada: 800-666-9162, ext. 522 